\title{
Determinants of Niger Seed Marketed Surplus Among Small Farm Households: The Case of Wama Hagalo Districts of East Wollega, Ethiopia
}

\author{
Melkamu Belina Negeri ${ }^{1} \quad$ Kumar Bar Das ${ }^{2}$ \\ 1. Assistant Professor of Economics, Wollega University, Nekemte, Ethiopia \\ 2. Professor of Economics, Visiting Professor at Wollega University, Nekemte, Ethiopia \\ Former Vice Chancellor, Fakir Mohan State Univ., Orissa, India
}

\begin{abstract}
Though agriculture continues to dominate the national economy of Ethiopia, both in terms of overall agricultural production and productivity, the sector suffers from major structural problems. The majority of farmers in Ethiopia are smallholders, producing mostly for own consumption and generating only a small marketed surplus. This study tries to assess the major determinants of marketed surplus particularly Niger seed. To conduct the study, both primary and secondary data sources were used. A multi stage sampling technique were applied to collect primary data from 120 small farm households. The study employed both descriptive statistics and econometrics model in the analysis of the data. Ordinary Least Squares(OLS) method were applied to assess the determinants of Niger seed marketed surplus in the study area. Prior to OLS estimation, the explanatory variables were tested for Multicollinearity and Heteroscedasticity. The result of the regression analysis shows that age of the households, Tropical livestock holdings, and farm size of the households significantly affects Niger seed marketed surplus in the study area.
\end{abstract}

Keywords: Niger Seed, Marketed Surplus, Households, Wollega, Ethiopia

DOI: $10.7176 / \mathrm{JESD} / 11-9-02$

Publication date:May $31^{\text {st }} 2020$

\section{Introduction}

Agriculture continues to dominate the national economy of Ethiopia, accounting for 72.7 percent of employment and 36.7 percent of its overall GDP. More than 79 million people in Ethiopia relies on agriculture for their livelihoods. Besides gold, Ethiopia's top five exports are all agricultural products (ATA, 2017). In the second Growth and Transformation Plan of Ethiopia, national development priorities have been given to the development of agriculture as it remains the mainstay of the nation's accelerated economic development (NPC, 2017).

Though agriculture is at heart of Ethiopian economy, both in terms of overall agricultural production and productivity, the sector suffers from major structural problems. Despite an average investment close to 13 percent of the total national expenditure, Ethiopian agriculture remains low input, low-value and subsistence oriented, and is vulnerable to frequent climatic shocks (UNDP, 2016). The failure of rains in the sector causes devastating drought conditions. Significant pasture and water deficits severely affects livestock dependent households in lowlands - extremely low milk production, and plummeted prices for livestock (FAO, 2017). Ethiopian economy which has shown 9.3 percent of average annual growth during the 2013/14 to 2017/18 fiscal years has recorded 7.7 percent growth in $2017 / 18$ fiscal year, slower than the growth rate registered in the previous year owing to growth deceleration in agriculture (NBE, 2018).

The majority of farmers in Ethiopia are smallholders, producing mostly for own consumption and generating only a small marketed surplus, portion of production which actually enters to the market (Alemayehu et al.,2012). For instance, in the 2017/18 fiscal year, 67.72 percent of the cereal crops produced were used for household consumption. Nearly 11.5 percent and 17.08 percent were used for seed and sale, respectively. The remaining 3.7 per cent of the cereals produced was used for other purposes like wages and animal feed. The pattern of oilseeds utilization is distinctly different from that of cereals in Ethiopia, for example, 23.69 percent of the Niger seed produced in the fiscal year were used for household consumption. 10.38 and 2.45 percent were used for seed and other purposes such as wages in kind respectively. Meanwhile, 63.47 percent of Niger seed were sold by small farm households (CSA, 2017). Thus, the study tries to assess the major determinants of Niger seed marketed surplus among small farm households particularly at Wama Hagalo district of East Wollega zone of Oromia as Niger seed is the major oilseed in the study area.

\section{Methodology}

\subsection{Description of the Study Area}

Wama Hagalo is one of the woredas in East Wollega zone of Oromia Region of Ethiopia. The woreda is bounded by Bilo Boshe in the east, Wayu Tuka in the west, Sibu Sire in the north and Jimma zone to the south. Mote is the capital town of the woreda located at a distance of about 90 kilometers from the zonal capital, Nekemte. The 
woreda is composed of 10 rural and 3 urban kebeles. Acording to the CSA (2013) projection, the total population of the woreda in 2017 is projected to 62,451 , out of this 31,459 are male and 30,992 are female. The woreda has a total coverage of $62,104.24$ hectares of land. In terms of land use pattern, 40,367.76 hectare is cultivable land, 10,122.99 hectares is grazing or pasture land, 5,278.86 hectare of land is covered with forest, and the remaing 6,334.63 hectares of land is for other uses. Agriculture is the primary income source of the households in the woreda. Maize, Sorgum, Teff, Niger, Barley, Broad Bean, and Millet are the major crops produced in the woreda.

\subsection{Data and Data Source}

The data for the study were gathered from primary and secondary sources. The primary data were collected through pre-tested semi-structured questionnaire. Secondary data were obtained from Central Statistical Agency (CSA), Governmental Organizations, and Woreda Offices, of Ethiopia.

\subsection{Sampling Method and Sample Size}

To collect primary data for the study, a multi stage sampling technique were adopted. First Wama Hagalo woreda was selected among the 17 woreda's of East Wollega zone since the woreda is well known in the production of Niger seed. In the second stage, 3 kebeles were selected from the 10 rural kebeles of the woreda. Finaly, from the 3 selected kebeles, sample small farm households were selected randomly based on probability proportional to size sampling technique.

The study used the simplified Yamane's (1967) sample size determination formula in setting the appropriate sample size at 95 percent confidence level, 0.5 degree of variability, and $0.9 \%$ level of precision( for having managable sample size). The formula is as follow;

$\mathrm{n}=\frac{\mathrm{N}}{1+\mathrm{N}(\mathrm{e})^{2}} \mathrm{n}=\frac{3,843}{1+3,843(0.09)^{2}} \quad \mathrm{n}=\frac{3,843}{1+3,843(0.0081)} \mathrm{n}=\frac{3,843}{1+31.13} \quad \mathrm{n}=\frac{3,843}{32.13}=120$

Where,

$\mathrm{n}=$ the sample size

$\mathrm{N}=$ the total number of rural households in the selected kebeles.

$\mathrm{e}=$ the level of precision

Table 1: Distribution of Sample Small Farm Households in the 3 kebeles

\begin{tabular}{|l|c|c|}
\hline Sample Kebeles & Total Small Farm Households & Sample Small Farm Households \\
\hline Bata Kusaye & 1,276 & 40 \\
\hline Meyisa Kombo & 1,088 & 34 \\
\hline Bata Wayu & 1,479 & 46 \\
\hline Total & $\mathbf{3 , 8 4 3}$ & $\mathbf{1 2 0}$ \\
\hline
\end{tabular}

Source: Own Computation

\subsection{Methods of Data Analysis}

The study employed both descriptive statistics and econometrics model in the analysis of the collected data. Descriptive statistics such as mean, ratio, percentages, and cross tabulations were used to describe the characteristics of small farm households in the study area. Ordinary Least Squares(OLS) regression model of Gujarati( 2004) was applied to assess the determinants of Niger seed marketed surplus among small farm households.

Econometric model specification of supply function in matrix notation;

Where: $Y_{i}=$ Marketed Surplus of Niger Seed

$$
Y_{i}=X^{\prime} \beta+U
$$

$X^{\prime}=$ Vector of explanatory variables

$\beta=$ Coefficient of the $i^{\text {th }}$ explanatory variable

$\mathrm{U}=$ disturbance term

The dependent variable in the model, marketed surplus of Niger seed, is a continuous variable measured in quintal. It shows the supply of Niger seed to the market by the farm households. It is also transformed into logarithm for data formalization. The hypothesis and definition of the independent variables used in the model are summarized in table 2 below. 
Table 2: Hypothesis and Definition of the Independent Variables

\begin{tabular}{|l|l|l|c|}
\hline \multicolumn{1}{|c|}{ Variable } & \multicolumn{1}{c|}{ Description } & \multicolumn{1}{c|}{ Type } & Hypothesis \\
\hline Sex & Sex of Household Head & Dummy & + \\
\hline Age & Age of Household Head & Continuous & + \\
\hline Family Size & Family Size of the Household & Continuous & + \\
\hline Dependency Ratio & Dependency Ratio of the Household & Continuous & - \\
\hline Education & Education Status of Household Head & Dummy & + \\
\hline Farm Size & Farm size owned by Households & Continuous & - \\
\hline Distance from Market & Distance from a Local Market to home & Continuous & - \\
\hline Frequency of DA & Frequency of DA in a Month & Continuos & + \\
\hline Tropical Livestock Unit & Tropical livestock holdings of the Household & Continuous & + \\
\hline Non/off Farm Income & Off/None Farm Income of the Household & Continuos & + \\
\hline Access to Credit & Access to Credit by the Households & Dummy & + \\
\hline
\end{tabular}

\section{Result and Discusion}

\subsection{Descriptive Statistics}

The results of descriptive statistics show that out of the total 120 sample farm households, 115 are male headed and 5 are female headed households. The mean age of sample farm households were 44 years old. On an average, 7 people lives in a farm households house in the study area. The mean dependency ratio in the study area were 1.18. On average, the farm households in the study area holds 3.39 hectare of lands. The mean Tropical livestock holdings of the households in the study area were 6.62 .

\subsection{Ordinary Least Squares Estimation}

Prior to OLS estimation, the explanatory variables were tested for Multicollinearity while the residuals were tested for Heteroscedasticity. The Variance Inflation Factor (VIF) technique were employed to detect multicolinearity, and Breusch- Pagen test for Heteroscedasticity. The VIF result in Apendix 1 shows the absence of series problem of multicollinearity. The result of Breusch-Pagen test $\left(\right.$ Prob $\left.>\mathrm{chi}^{2}=0.08\right)$ also reveals the non existance of problem of Heteroscedasticity.

The result of OLS in table 3 below shows that the age of the households, Tropical Livestock holdings, and Farm size of the households significantly affects Niger seed marketed surplus in the study area. The F-test value of $\mathrm{F}(11,108)=5.00$, and R-square of value of 0.34 indicates the statistical significance of the regression model. Table 3: OLS estimation Result

\begin{tabular}{|c|c|c|c|c|c|}
\hline LMarketedSNS & & Coef. & Std. Err. & $\mathbf{t}$ & $\mathbf{P}>|\mathbf{t}|$ \\
\hline Sex & & 0.3525 & 0.2721 & 1.30 & 0.198 \\
\hline Age & & -0.0117 & 0.0047 & -2.44 & 0.016 \\
\hline Family Size & & -0.0108 & 0.0207 & -0.53 & 0.600 \\
\hline Dependency Ratio & & -0.0702 & 0.0628 & -1.12 & 0.267 \\
\hline Education & & 0.1589 & 0.1267 & 1.25 & 0.213 \\
\hline Farm Size & & 0.1052 & 0.0356 & 2.95 & 0.004 \\
\hline Distance from Market & & 0.0060 & 0.0084 & 0.71 & 0.481 \\
\hline Frequency of DA & & -0.0303 & 0.0465 & -0.65 & 0.516 \\
\hline Tropical Livestock Unit & & 0.0494 & 0.0172 & 2.88 & 0.005 \\
\hline Non/off Farm Income & & -0.4390 & 0.1373 & -0.32 & 0.750 \\
\hline Access to Credit & & -0.1626 & 0.1230 & -1.32 & 0.189 \\
\hline Constant & & 0.2937 & 0.4092 & 0.72 & 0.474 \\
\hline Number of obs & $=$ & 120 & & & \\
\hline $\mathrm{F}(11,108)$ & $=$ & 5.00 & & & \\
\hline Prob $>$ F & $=$ & 0.000 & & & \\
\hline R-squared & $=$ & 0.3373 & & & \\
\hline Adj R-squared & $=$ & 0.2698 & & & \\
\hline Root MSE & $=$ & 0.5669 & & & \\
\hline
\end{tabular}

Source: Own result

${ }^{* * *}$ and ${ }^{* *}$ indicate the level of significance at $1 \%$ and $5 \%$ probability level respectively.

\section{Summary and Conclusion}

Agriculture is at heart of Ethiopian economy however, both in terms of overall agricultural production and productivity, the sector suffers from major structural problems. Despite an average investment close to 13 percent of the total expenditure, Ethiopian agriculture remains low input, low-value and subsistence oriented, and is 
vulnerable to frequent climatic shocks. Ethiopian farmers produce mostly for own consumption and generating only a small marketed surplus. Thus, this study tried to assess the major determinants of Niger seed marketed surplus among small farm households particularly at Wama Hagalo district of East Wollega zone of Oromia as Niger seed is the major oilseed in the study area.

The data for the study were gathered from both primary and secondary sources. The primary data were collected through pre-tested semi-structured questionnaire. Secondary data were obtained from Central Statistical Agency (CSA), Governmental Organizations, and Woreda Offices.

A multi stage sampling technique were applied to collect primary data from randemly selected 120 farm households in the study. The study employed both descriptive statistics and econometrics model in the analysis of the collected data. Descriptive statistics such as mean, ratio, percentages, and cross tabulations were used to describe the characteristics of small farm households in the study area. Ordinary Least Squares(OLS) regression model of were applied to assess the determinants of Niger seed marketed surplus among small farm households in the study area.

Prior to OLS estimation, the explanatory variables were tested for Multicollinearity while the residuals were tested for Heteroscedasticity. The result of OLS regression shows that the age of the households, Tropical Livestock holdings, and Farm size of the households significantly affects Niger seed marketed surplus in the study area.

\section{Reference}

Alemayehu Taffesse, Paul Dorosh, and Sinafikeh Asrat, 2012. Crop Production in Ethiopia: Regional Patterns and Trends, Summary of ESSP II Working Paper 16, IFPRI, Addis Ababa

ATA, 2017. Agricultural Transformation Agency, Agricultural Transformation Agenda Annual Report of the 2016/17.

Central Statistical Agency (CSA), 2013. Population Projection of Ethiopia for All Regions At Wereda Level from 2014 - 2017, Federal Demographic Republic of Ethiopia, Addis Ababa Ethiopia.

CSA, 2018. Agricultural Sample Survey, Crop and Livestock Product Utilization, Volume vii, Addis Ababa.

FAO, 2017. Ethiopia August Situation Report, Addis Ababa, Ethiopia

GAIN, 2018. Global Agricultural Information Network, Ethiopia's Oilseed Sector Set to Expand, GAIn Report Number:ET1826, FAS, Addis Ababa.

Gujarati, 2004. Basic Econometrics, Fourth edition. The McGraw hill Company, In United States Military Academy, West Point.

NBE, 2018. National Bank of Ethiopia 2017/18 Anual Report, Addis Ababa, Ethiopia.

NPC (National Plan Commission), 2017. The 2017 Voluntary National Reviews on SDGs of Ethiopia: Government Commitments, National Ownership and PerformanceTrends, Addis Ababa

UNDP, 2016. United Nations Development Programme, Agricultural Growth and Transformation, Strengthening National Capacity through Sustainable Increases in Agricultural Production and Productivity.

Yamane Taro (1967). Statistics an Introductory Analysis. 2nd Edition, New York, Harper and Row.

\begin{tabular}{|c|c|c|}
\hline Ap & $\begin{array}{l}\text { adix } \\
\text { linear }\end{array}$ & t Result \\
\hline Variable & VIF & 1/VIF \\
\hline Age & 1.73 & 0.577383 \\
\hline Tropical Livestock Unit & 1.71 & 0.583096 \\
\hline Family Size & 1.71 & 0.585390 \\
\hline Farm Size & 1.56 & 0.639428 \\
\hline Access to Credit & 1.37 & 0.731855 \\
\hline Education & 1.36 & 0.732761 \\
\hline Dependency Ratio & 1.31 & 0.763179 \\
\hline Frequency of DA & 1.27 & 0.787029 \\
\hline Non/off Farm Income & 1.23 & 0.814109 \\
\hline Distance from Market & 1.20 & 0.832671 \\
\hline Sex & 1.10 & 0.905245 \\
\hline
\end{tabular}

